\title{
THE PROLOGUE TO OUR LIVES
}

To STUDY AND REANIMATE the past, scholars need to know the past when it was the present. There is no other way to reconstruct the life and thought that preceded us. The past cannot be confronted on the information superhighway.

Where, then, can authors and editors, curators and archivists, librarians and scholars meet the past face to face if not on electronically controlled nets and lines and Webs? Only in the actual books that were printed in the past, the letters that were written in the past, the notes that were scribbled in the margins of pages in the past, the ephemeral broadsides and pamphlets that were composed and circulated in the past. Such materials are more than reflections of a bygone time, they are the bygone time.

As we wrote in our recently published New Worlds in Old Books: "How do we resurrect the fires and floods, the battles and plagues, the births and deaths, the murders and executions, the coronations and celebrations, the pacts and assemblies that preceded us?" Surely it is from on-the-spot eye-witness reports of events that later generations remember earlier ones: letters written and saved; accounts in primitive newssheets; royal or parliamentary announcements; especially printed records in the form of ephemeral pamphlets read and thrown away, nailed to walls and blown away. From the few that have survived ... Written often in great haste, printed in small numbers, scanned and tossed aside-we touch the fabric of our past. Here are ... the source materials that ... make our history." Those source materials are today special collections, and the fact that they, and not their electronic reproductions, make our history is what makes them special. 
What electronic process can reproduce the touch and feel of an incunable Book of Hours, an Aldine quarto, the immediacy of an Elzevier duodecimo designed to fit into the pocket so that he who runs may read, a first edition of Voltaire or Rousseau, the original appearance of a plea for utopian government or perennial peace, the startling revelations of Charles Darwin aboard the Beagle? Nothing in cyberspace can convey the character and substance of the original. It is the original that embodies the past and transports the past into the present. The firsts of Grotius, Newton, Mary Wollstonecraft, Shelley cannot be electronically duplicated. These are part of our special collections and, as such, must be preserved and consulted.

Their place is in the Special Collections Division of the library. They convey to their readers the past that is otherwise irretrievable. They report the events and climate of times gone by, from a sixteenth-century mugging to the Battle of Waterloo, from the discovery of a new world to the horrors of slavery, from the stratagems of witchcraft to the spread of humanitarianism. Nowhere but in original texts can the past come alive. Collected and carefully assembled, such sources unfold for us the prologue to our lives. Through them we learn the history of the human race, its discoveries, its disasters, and its triumphs. These are special collections indeed that provide us and those who will follow us with a collective memory. 